\title{
The Impact of Work Stress on the Performance of Field Facilitators Staff of Self- Help Housing Stimulant Assistance Program in Magelang with Job Satisfaction as Mediation
}

\author{
Nenden Nur Annisa \\ University of Muhammadiyah \\ Purworejo Purworejo, Indonesia \\ Nendennurannisa12@gmail.com
}

\begin{abstract}
This study has purpose to determine the impact of job stress on the performance of the field facilitators staff of self-help housing stimulant assistance program in Magelang with job satisfaction as mediation. This study applied a questionnaire in the primary data collection and a quantitative approach. The sample used in this study was 84 contract employees who worked for the Self-Help Housing Stimulant Assistance in Magelang Regency. The sampling in this study was done using random sampling technique. The data analysis in this study was by using multiple linear regression analysis. The results of the significant probability of the variable relationship were measured by using the $t$ test and the intervening test using the sobel test. The results in this study indicated that job stress has no effect on job satisfaction. Job satisfaction has no effect on employee performance. Job stress has a positive and significant effect on employee performance. Therefore, job stress has a direct effect on employee performance and job satisfaction does not act as an intervening variable, since satisfaction cannot explain the indirect effect between job stress variables through satisfaction toward performance.
\end{abstract}

Keywords: Job stress, Job satisfaction, Employee performance

\section{INTRODUCTION}

Performance is the fulfillment of tasks or skills related to an employee's job. Job performance is defined as actions that contribute to organizational goals and are under individual control. This is related to the willingness and openness to try and achieve new aspects of work which in turn will lead to an increase in individual productivity, measured through the level of achievement of goals and business and social responsibility. The key indications of job performance are individual personal characteristics including competence and ability to handle the role conflicts. (Hamid and Narehan, 2015).

The Government Organization, the Ministry of Public Works and Public Housing (PUPR) has a SelfHelp Housing Stimulant Assistance Program (BSPS) which is a program that aims to provide livable houses for the community. This program is widely known as the home renovation program. The success of implementing the self-help housing stimulant assistance is inseparable from the human resources who work in it, called by the Field Facilitator Staff (TFL).

The adjustment of employees in the workplace is a matter of concern for all organizations regardless of all factors and conditions. As a result, employees are considered a very important asset for their organization (Qureshi and Ramay, 2006). Problems arise for the organizations when they begin to understand that their organization is performing at the best level and with high efficiency, there is no need for further improvement in their organization (Summers and Hyman, 2005).

Zafar, Qadoos (2015) employee performance where an individual successfully completes the tasks set by the organization, according to predetermined standards along with efficient resource utilization in a changing environment. Nevertheless, during formal work activities, employees may experience physical symptoms, psychological and social influences that can cause stress.

Taurani (2012) one of the biggest challenges in management is implementing effective human development and making strategies to improve organizational performance. performance organizations emerge within the time-frame of providing high quality service and customer satisfaction. Frequent small conflicts between employees or between superiors and subordinates or vice versa due to errors or differences in perceptions. In the preparation of a good system, it will not be implemented if there is no support for working conditions, good leadership and communication, an unfavorable atmosphere will result in work stress. Raziq, Abdul (2015) stated that most businesses ignore the work environment in their organizations. This can have a negative effect on the employee performance.

Stress causes imbalances in a person's life, because it causes depression and thereby damages health, attitudes and work behavior. The causes of stress are called stressors, which can lead to conflicts in the workplace. (Ali, Warraich., Et. Al. (2014). Michael (2009) Stress at work is a well- known phenomenon that may express itself differently, and affect different workers, in different work contexts. Job stress is 
wrong. One thing that is important for the company, especially regarding employee performance, is seen as a precursor to job satisfaction. Raza, Ali (2014) Job stress directly affects job satisfaction. The inverse relationship between job stress and job satisfaction between various populations is found to be consistent in the literature. In an international context, there is a large body of literature documenting the effect of job stress on employee job satisfaction. The stress experienced by employees due to the environment they face will affect their performance and job satisfaction.

Job satisfaction is one of several factors of work efficiency in general. From a psycho- sociological perspective, job satisfaction arises as a result of the difference between what individuals get in return for their work and what they think they are expected to achieve. (Camelia, Bazgan. M. and Bazgan, M, 2011). Job satisfaction reflects an employee's attitude towards his job. In carrying out their duties, the company leadership certainly cannot be separated from problems related to employee satisfaction. Employee job satisfaction is a factor that is of great concern. Therefore, an assessment of employee job satisfaction is carried out, which is measured by the relationship between leaders and employees, division of tasks and similarity or suitability of work programs. According to Rivai (2010), "Satisfaction is an evaluation that describes someone's feelings of attitude, happy or not happy, satisfied or dissatisfied at work".

The phenomena of job stress and job satisfaction that have been described above are believed to affect the formation of employees and have an impact on employee performance improvements at every level of the organization. This research is very relevant to improve the performance of the Field Facilitator of BSPS. The efforts to improve performance will of course be greatly influenced by the employee behavior. Various views and efforts have been carried out to improve employee performance, but basically it must be started with efforts to build motivation in employees, build good

communication and create a comfortable work environment so that the mindset becomes better as well.

Based on the theoretical explanation and previous research that the theme taken really explains the conditions in the field which is to find out the impact of work stress of the Field Facilitators for the Community Self-Help Housing Stimulant Assistance in Magelang on employee performance with job satisfaction as a mediating variable.

\section{A. Work Stress}

\section{LITERATURE REVIEW}

Handoko, 2011 Job stress is a tension condition that affects one's emotions, thought processes, and conditions in carrying out work. Leung (2011) stress is a psychological attitude that may occur in a person every day. People in stressful environments generally face unachievable job demands, experience different bodily reactions, such as headaches, back pain, or even thirst, and have a variety of subjective feelings, such as dissatisfaction, unhappiness, sadness, and depression. Job stress is defined as a concept that builds up thoughts in the minds of employees, these thoughts can vary according to the situation and environment. All thoughts are processed in the mind, be it good or bad, develop attitude and then behavior. (Zafar, Qadoos: 2015).

\section{B. Job Satisfaction}

Robbins, 2015 job satisfaction is a positive feeling about work, which results from an evaluation of its characteristics. Tivallas, Panagiotis, et. al, (2013) job satisfaction, one of the most studied issues in the relevant literature. Job satisfaction can be defined as a pleasant emotional state that results from a person's job appraisal that achieves or facilitates the achievement of job values. (Paramita, 2016) job satisfaction has a relationship with a collection of pleasant and unpleasant feelings from employees in an organization or company when working.

\section{Employee Performance}

Robbins (2003) states that employee performance is a function of the interaction between ability and motivation. Mathis and Jackson (2006: 65) state that performance is basically what employees do or don't do. Meanwhile, Zafar, Qadoos (2015) shows the performance of employees that an individual manages to complete the tasks set by the organization, according to predetermined standards along with efficient resource utilization in a changing environment. However, during formal work activities, employees may experience physical symptoms, psychological and social influences that can cause stress.

\section{RESEARCH METHOD}

The research method used in this study was a quantitative research methods. This study applied a survey approach. The measurement scale in this study was a Likert scale with a score of 1- 5 using a systematic sampling technique. The data obtained were processed using the SPSS Statistic

19 program. The population in this study were the Field Facilitators for Self-Help Housing Stimulant Assistance in Magelang Regency with a total sample of 84 TFL.

\section{DISCUSSION}

\section{A. The effect of job stress on employee job satisfaction}

This study is different from the results of research by Raza, Ali which explains that job stress affects job satisfaction, where the research of Raza takes respondents as a sample of commercial banks in Pakistan, namely bank managers, so that the research of Raza can explain that job stress can explain the variant of the model. on satisfaction, in contrast to research that is being conducted where job stress has no effect on job satisfaction because because in this study taking respondents as a sample, namely BSPS Field Facilitators in Magelang district where the level of stress in their performance is not too heavy and can 
still be controlled by them.

This research is also different from research by Paramita (2016) which states that job stress has a significant positive effect on changes in job satisfaction. Job satisfaction has a relationship with a collection of pleasant and unpleasant feelings from employees or employees in an organization or company when working and the dynamic nature of job satisfaction felt by them. From the research results, it is known that most of the Field Facilitators for Self-Help Housing Stimulant Assistance in Magelang Regency assess that work stress does not dominate their job satisfaction. For example, such as the stress of the tasks assigned to the Field Facilitators, more or less the level of the workload does not affect the level of satisfaction of employess The results of this study support previous research conducted by Dhania (2010), showing that job stress does not have a significant effect on job satisfaction. Dhania explained that with very little effect, it means that it cannot explain job stress to job satisfaction. Dhania also said that the higher the work stress, the perceived job satisfaction can be high or low. Likewise, on the other hand, the smaller the work stress, the perceived job satisfaction can be high or low. Similar to the research of Khuzaeni (2013) and Anwar (2015), the results of job stress analysis on job satisfaction show no significant effect.

\section{B. The Effect of job satisfaction on employee performance}

Job satisfaction does not have a significant effect on employee performance is shown by the results of the hypothesis test. The results of this study do not support previous research where job satisfaction in the research by Arifin, H. Muhammad (2015) proves that job satisfaction has a positive and significant effect on performance, which means that the higher the job satisfaction, the higher the performance. Further research by Anwar, Andi. B, et. al. (2015) also stated that job satisfaction has a positive and significant effect on employee performance.

Them feel fast for their attention, from all the aspects that the organization/ superiors give to the Field Facilitators, where social relations, long- term opportunities have yet to be felt by the District Field Facilitators in Magelang in working in the Self-Help Housing Stimulant Assistance Program in Magelang, so that the supervisors of the BSPS Program need to paid more attention on this factor, where the TFLs (Field Facilitator Staff) still have very minimal job satisfaction in the organizations they are engaged in.

\section{Job stress on employee performance}

The results of this study support the results of previous studies Olusegun, et al. (2014) stated in their research that there is a positive

and significant influence between job stress on employee performance. Stress is a psychological attitude that may happen to someone every day. People in stressful environments generally face unachievable work demands, experience different bodily reactions, such as headaches, back pain, or even thirst, and have a variety of subjective feelings, such as dissatisfaction, unhappiness, sadness, and depression.

This is in line with the results of Astianto's (2014) research which shows the positive influence of work stress on employee performance. Noviansyah (2011) is in line with increasing stress, performance tends to increase, because stress helps employees direct all resources to meet work needs, is a healthy stimulus that encourages employees to respond to job challenges. Finally, the stress reaches a stable point which roughly matches the employee's performance abilities. Furthermore, if the stress becomes too great, performance will begin to decline because stress interferes with work execution. Employees lose the ability to control it. The most extreme result is zero performance, employees become unable to work, give up, leave or refuse to work to avoid stress. Furthermore, this study supports the research of Zafar, Qadoos, et. al. (2015) which shows that job stress has a positive and significant effect on employee performance.

This study is also different from the previous research above, where this study does not support previous research conducted by Khuzaeni (2013). The results of the analysis state that job stress has no significant effect on employee performance. This study is also not the same as the research by Paramita, Lalujan, et. al. (2016), which states that work stress has a negative and insignificant effect on employee performance.

Stress is an inseparable and avoidable part of life. However, if used properly, stress can also have beneficial results. From the results of this study it can be concluded that the increase in employee performance by leaders who always play an important role, in the performance of employees, the supervisors in the BSPS Program must pay attention to certain levels of stress on employees in order to increase the efficiency and effectiveness of their TFL. If work stress has a negative effect, it can be hopelessness, depression, lack of self- confidence, reduced employee productivity, reduced levels of motivation, low determination in the workplace and lack of job targets. All of these effects can have more harmful consequences for the organization if employee commitment to the organization decreases, high absenteeism, low morale, poor psychological and health conditions and low levels of motivation. If stress is not managed properly, it can be dangerous for employees and the organization in affecting the productivity of workers.

The stress management that occurs in TFL is currently good, where the work stress experienced by the average employee is not so high and can be controlled by each TFL, because it is still positive for performance, attention to work stress is needed in the organization to minimize stress levels to keep performance improving.

\section{The effect of job stress on employee performance through job satisfaction}

Based on the results of statistical calculations that job satisfaction cannot be a mediating variable in the 
relationship between job stress and employee performance. In this study, the results showed that job stress has no effect on job satisfaction, job satisfaction also has no effect on employee performance. Since in this study, job stress has a direct effect on employee performance positively and significantly

\section{CONCLUSION}

Based on the results of the study on the impact of work stress on the performance of the community housing self-help assistance field facilitators in Magelang with job satisfaction as a mediating variable, which has been described above, the following conclusions can be drawn:

- Job stress has no effect on job satisfaction of Field Facilitators.

- Job satisfaction has no effect on the performance of Field Facilitators.

- Work stress has a positive and significant effect on the performance of Field Facilitators.

From the results of the path analysis of the mediating variables (intervening) showed that the use of job satisfaction as an intervening variable in order to improve the performance of Field Facilitators, it is known that the indirect effect of job stress on performance through job satisfaction of the Field Facilitators is smaller than the direct effect of job stress on the performance of the Field Facilitators. This means that to improve the performance of the Field Facilitators can be done directly through work stress variables on performance. Thus, factors that can cause high performance through work stress should obtain high attention.

\section{REFERENCES}

[1] Afrizal , Poundra Rizky . 2014. "Effects of Conflict an Stress Working Against satisfaction Work (Study on Employee PT.TASPEN(Pers ero) Branch Malang)". Journal of Business A dministration (JAB). Vol. 8 No, 1. Pg. 1-10

[2] Agarwal,Richa.N.2015."Stress,Job Satisfaction\& Job Commitment's Relation With a ttrition With Special Reference to the Indian IT Sector". Managementand Innovation For Competitive Advantage . Vol. 6 No. 5, pp. 720- 731.

[3] Ali, Warraich . U., Ahmed, RR, Ahmad, N. and Khoso . I. (2014). " Impact of Stress on Job Performance: An Empirical study of the Employees of Private Sector Universities of Karachi, Pakistan ". Research Journal of Management Sciences . Vol. 3 No. 7, pp. 14-17.

[4] Armstrong, M . 2009. Human Resource Management Practice .London, philadelphia : Kogan pag e .

[5] Astianto , Anggit \&Heru Suprihhadi. 2014." Effects of Stress Work And Expense Work To Perfor mance Employees PDAM Surabaya". Journal of Management Science and Research . Vol. 3 No. 7, pg.

[6] Ardiansyah,DO.2016."Effectof Communication To Performance Employees With Mediated By Satisfaction Work". Journal of Business and Management . Vol. 3 No.1, pp. 16-30.

[7] Arifin , H. Muhammad. 2015. "The Influence of Competence, Motivation, and Organizational Culture to High School Teacher Job Satisfaction and Performance ". International Education Studies . Vol. 8 No. 1, pp. 38-45.

[8] Awadh, Ibtisan. M., Lucy, G. and Anwar. HA 2015. "Effects of Workplace Stress on Employee Performance in the County Governments in Kenya: A Case Study of Kilifi County Government". International Journal of Scientific and Research Publications. Vol 5 No. 10., Pp. 1-8.

[9] Aziri,Brikend. 2011." Job Satisfaction: A Literature Review". M anagement Research and Practice . Vol . 3 No. 4 . pp. $77-86$

[10] Bemana , S ,, Hamideh , M . Mohsen , G ., Sayed , M . T. and Amir , H . G . 2013. "The Relationship among Job Stress and Job Satisfaction in Municipality Personnel in Ira n". World Applied Sciences Journal . Vol. 22 No. 2, pp. 233-238 .

[11] Bitmis.M.Gokhan\&Azize,E.2012." The Moderating Effect of Work Stress on the Relationships B etween Dimensions of Leader Mbucket Exch ange and Job Satisfactions". Journal of Globa Strategic Management. Vol. 6 No. 1, pp. 112-120.

[12] Bajpai, J . V ., Trupti , V . D . and Siddharth , B . 2015"A Study of Impact of Work Stress on Job Satisfaction of Employees Working in Indian Banking Sector". International Journal of Business Quantitative Economics and Applied Management Research. Vol. 1 No. 11, pp. 27 32.

[13] Camelia , Bazgan . M. and Bazgan , M. 2011. "Stress Management and Work Performance - A Case Study". Journal of Engineering Studies and Research . Vol. 17 No. 3, pp. 11-17 .

[14] Dhania , Dhini Rama. 2010. "Effects of Stress Work, Expenses Working Against Satisfaction Work (Study On Medical Repres entative in the Holy City)". Muria Kudus University Psychology J ournal . Vol. I No. 1, pg. 15-23.

[15] Fadli , Uus Md. 2012. "Effectof Satisfaction Work To Performance Lecturer University Singaper bangsa Karawang ". Management Journal . Vol. 9 No. 2. Pg. 678704.

[16] Febrianto ,R., and Dewie ,TW.2014. "Effectsof Com mitment Organization And Stress Work To P erformance". Journal of Management Scienc e. Vol. 2 No, pg. 941-951.

[17] Ghozali,Imam . 2011 . Theory , Concepts , and Appl ications with SPSS17. Semarang: Diponegor o University Publishing Agency .

[18] Ghozali, Imam. 2011. Concepts and Applications with the Amos 19.0 Program . Semarang: Diponegoro University Publishing Agency.

[19] Hamid, Nur. ZA and Narehan, H. 2015. "The Relationship Between Workplace Environment and Job Performance in elected Government Offices in Shah Alam, Selangor".International Review of Management an Business Research . Vol. 4 No. 3 , pp. 846-851.

[20] Handoko , T.Hani. 2011. Management : Issue 2. Yogyakarta: BPFE.

[21] Hendriani ,Susi and Fitri ,H. ,2014. "Effectsof Motiv ation And Communications To Performance Employees Papers Secretariat of the Regional Province of Riau". J u rnal Business Applications . Vo 1. 4 No. 2 , pg. 124- 156.

[22] Iqbal, Muhammad and Muhammad, AW 2012. " Impact of Job Stress on Job Satisfaction among Air Traffic Controllers of Civil Aviation Authority: An Empirical Study from Pakistan ". International Journal of Human Resource Studies . Vol. 2 No. 2, pp. 53-70.

[23] Jehangir, Muhammad., Nasir. K., Ayaz,K. Muhammad, TJ and Shaheed, S. 2011. "Effects of Job Stress on Job Performance \& Job Satisfaction". Interdisciplinary Journal o f Contemporary Research in Business . Vol. 3 No. 7, pp. 453-465.

[24] Khuong, M . N . and Vu , H . Y . 2016. "Investigate the Effects of Job Stress on Employee Job Performance - A Case Study at Dong Xuyen Industrial Zone, Vietnam". International Journal of Trade, Economics and Finance. Vol. 7 No. 2 , pp. 31-37.

[25] Khuzaeni , M S., K. , D . and Solimun . 2013. " The Influence of Work Culture, Work Stress to the Job Satisfaction and Employees Performance in the State Treasury Service Office in Jakarta, Indonesia ". IOSR Journal of Business and Management (IOSR- JBM) . Vol. 9 No. 2 , pp. $49-54$ 
[26] Kotteeswari, M. and S. Tameem .S. 2014. "Job Stress and its Impact on Employees ' Performance US Tudy with Reference to Em ployees Working in BPOS ". International Journal of Business and Administration Research Review . Vol. 2 No. 4 , pp. 18-25.

[27] Kristin, Juwita. 2012. "Analysis of Job Rotation, Organizational Communication and Its Effect on Performance Through Employee Job Satisfaction (Study in Malang Islamic Hospital)". Journal of Economic Research and EXIS Business. Vol. 7 No. 3, pg. 180- 190

[28] Kumari , Neeraj . 2011. " Job Satisfaction of the Employees at the Workplace". European Journal of Business and Management . Vol . 3 No. 4 , pp. 11-30.

[29] Kurniawan, Deny. 2008. Distribution Table . F Orum Statistics http://ineddeni.wordpress.co m. Ret rieved 11.15 WIB. 17 May 2017.

[30] Kusuma , Galih Candra . 2015."Effectof Motivation and Training To Performance". Journal of B usiness Administration (JAB). Vol. 21 No. 1.

[31] Leung, Mei-Yung., Yee , S . I . C . and Chen, D. 2011. "Structural Linear Relationships Between Job Stress, Burnout, Physiological Stress, and Performance Construction Project Managers". Engineering, Construction and Architectural Management . Vol. 18 No. 3 , pp . 312-32

[32] Nunnally , J. 1970. Introduction to Psychological Measurement. York: McGraw Hill Book Company.

[33] Olusegun, A . J ., And Ajani , J . O . and Olabisi , O . 201 " A n $\mathrm{O}$ verview of the $\mathrm{E}$ ffects of $\mathrm{J}$ ob $\mathrm{S}$ tress on $\mathrm{E}$ mployees $\mathrm{P}$ erformance in $\mathrm{N}$ igeria $\mathrm{T}$ eritiary $\mathrm{H}$ ospitals". Economics. Vol. 60. No. 4, pp. 139-153.

[34] Paramita ,L .,Victor, PKL. and Greis. M.S. 2016. "Effect Komunikasai Organization And Stress Work Against Satisfaction Work And ItsImp act To Performance Employees InCompanies Public Bulog Division Regional North Sulawesi". EMBA Journal . Vol.4 No.1, p. 131- 142 .

[35] Qureshi , M. T and Ramay, IM 2006. Impact of Human Resource Management Practices on Organizational Performancein Pakistan . Muhammad Ali Jinnah University: Islamabad

[36] Raza , Ali and Muhammad, I. 2014. "Impact Of Stress on Job Satisfaction of Managerial Employees Working in Commercial Banks: a Case Study of District Ghotki Sindh. Europea n". Journal of Business and Management . Vol. 6 No. 31 , pp. 330- 335.

[37] Raziq, Abdul \& Raheela, M. 2015. "Impact of Working Environment on Job Satisfaction". Procedia Economics and Finance. Vol. 23, pp. 717-725.

[38] Saranani , Dawn . 2015. "Role Conflict and Stress Effect on The Performance of Employees Working in Public Works Department ". The International Journal Of Engineering And Science (IJE S) . Vol . 4 No. 6, pp. 1-10 .

[39] Sedarmayanti . 2011. Building and Developing Lead ership and Improving Performance to Achiev e Success . Bandung: Refika Aditama.

[40] Summers J., and Hyman J. 2005 . Employee participation and company performance; A review of the literature University of Aberdeen. Joseph Rowntree Foundation.

[41] Taurani, A. \& Sadegh,R. 2012. "Effect of Employees Communication and Participation on Employees Job Satistification: An Empirical Study on Airline Companies in Iran". International Conference on Economics, Trade and Development IPEDR, IACSITPress, Singapore . Vol. 3 No. 6 , pp. 52-56

[42] Trivellas , P ., Panagiotis , R . and Charalambos , P . 2013. " The effect of job related stress on employees' satisfaction: A survey in Health Care ". Procedia -Social and Behavioral Sciences . Vol. 73 . pp. 718-726.

[43] Welch, Mary. 2011. "The evolution of the employee engagement concept: communication implications for Corporate Communications". An International Journal. Vol. 16. No. 4, pp. 328-346 Organiizational Employees UD ULAM SARI DENPASAR. Thesis . Master
[44] Zafar, Qadoos., Ayes, A., Tayyab, H., Toqeer, I. and Hafiz, IY 2015. "The Influence of Job Stress on Employees Performance in Pakistan". American Journal of Social Science Research.Vol.1.pp.221-225, 